\title{
Genetic Characterization of Viral Nervous Necrosis Infects Tilapia (Oreochromis sp.) in Indonesia
}

\author{
$\underline{\text { Uun Yanuhar }}^{1,)^{*}}$ Novia Christi ${ }^{2,(b)}$ and Diana Arfiati ${ }^{1,(c)}$ \\ ${ }^{1}$ Faculty of Fisheries and Marine Science, Brawijaya University, Jl. Veteran, Malang, 65145, East \\ Java, Indonesia \\ ${ }^{2}$ Fish Quarantine and Inspection Agency, Jl. Raya Bandar Udara Ir. H. Juanda No. 23 - Sidoarjo \\ 61254 - East Java, Indonesia \\ ${ }^{\text {a)} C o r r e s p o n d i n g ~ a u t h o r: ~ u u n y a n u h a r @ y a h o o . c o m ~}$ \\ b)novia_christi@yahoo.com \\ c)d_arfiaty@yahoo.com
}

\begin{abstract}
Tilapia (Oreochromis sp.) is the most important cultured fish in the 21 century and Indonesia is the country's second largest tilapia producer after China. It make Indonesia should be more concerned with any possible attack diseases that can infect both from the class of parasites, fungi, bacteria, and viruses especially Virus Nervous Necrosis (VNN). The existence of VNN in tilapia is one of the problems that must be handled. In the present research, a natural outbreak of VNN in tilapia (Oreochromis sp.) farmed in mid-Java in Indonesia was investigated using molecular genetic characterization. Research conducted using Reverse transcriptase PCR (RTPCR) methods, sequencing analysis, and phylogenetic analysis. the construction of phylogenetic trees is based on the neighbor-joining method using software MEGA6. The samples used are a tilapia juvenile size 5-7 cm, with or no clinical symptoms, and taken at random in the cultivation of tilapia in Central Java. It showed that the tilapia juvenile infected VNN show changes and damage to the organs and tissues. It can be seen from the examination of clinical symptoms, anatomic pathology and histopathology. DNA of the tilapia infected by VNN was 294 bp on both the brain and the eyes organ. Phylogenetic analysis results showed that VNN from infected tilapia was the same as snapper and grouper and has the closest kinship with genotype Redspotted grouper nervous necrosis virus (RGNNV), which is about $99 \%$. It can be stated that Betanodavirus in freshwater fish potential is derived from Betanodavirus in seawater fish.
\end{abstract}

Keywords: Viral nervous necrosis, tilapia, genetic expression, phylogenetic

\section{INTRODUCTION}

Tilapia (Oreochromis sp.) is the most important cultured fish in the 21 century [1]. It has been introduced into over 90 countries, and increasingly used worldwide in aquaculture (Bigarré et al., 2009), because it is ease to grow and reproduce in a wide range of environmental conditions [3].The aquaculture production of tilapias was about 2.5 million tons annually,and they serve as a primary protein source in the developing world [4]. The production of tilapia in ponds in Indonesia in 2013 reached 324.984 tons, with an production increase reach $43.18 \%$ per year [5]. This result puts Indonesia as the country's second largest tilapia producer after China. With so many manufactured products, making Indonesia should be more concerned with any possible attack diseases that can infect both from the class of parasites, fungi, bacteria, and viruses.

Viral Nervous Necrosis (VNN), or Viral Encephalopathy and Retinopathy (VER) is the family Nodaviridae that attracted the attention of fish health workers during the last decade. The 
virus character is a non-enveloped, icosahedral, single-stranded positive-sense RNA virus. It comprises of two segments: a gene encoding an RNA-dependent RNA polymerase (RNA1) and the capsid protein (RNA2) [6][7]. Phylogenetic analysis show that fish Noda viruses have been classified into 4 major genotypes: designated tiger puffer nervous necrosis virus (TPNNV), striped jack nervous necrosis virus (SJNNV), berfin flounder nervous necrosis virus (BFNNV), and redspotted grouper nervous necrosis virus (RGNNV). This phylogenetic was based on similarities in the partial RNA2 sequences encoding the C-terminal halves of the coat proteins[8]. Virus is recorded from over 40 fish species covering different geographic locations [9]. The disease was first obtained from larvae of Japanese parrot fish (Oplegnathus jasciatus), barramundi (Lates calcarifer), turbot (Scophthalmus maximus), in Japan [10], Australia [11], Norway [12], respectively.

In Indonesia,VNN disease events was first reported in 1997, in Banyuwangi, East Java,on the cultivation of barramundi (Lates calcaliver). It spread to Bali in 1998, and expanded to grouper hatchery in Bali that caused mass deaths of $100 \%$. This VNN were grouped in SJNNV [13]. This disease have resulted in mass deaths of marine aquaculture fish, particularly the larval and juvenile stages [14][15].

VNN attacks can be transmitted vertically from an infected mother VNN [9] or horizontally through infected fish [16][17] as well as from the rest of the fish (trash fish) or molluscs used as feedin the aquaculture [18]. VNN infected fish show the symptoms such as abnormal swimming behavior (circling or whirling), floats above the stomach, decreased appetite and body color gel [15].The virus concentrate in the retina, brain, and spinal cord of infected fish. Infected fish demonstrate erratic swimming patterns and the neurological abnormalities, including cellular necrosis andvacuolization in the retina and the system of central nervous [19]. Some studies suggest that the VNN was not only attack the sea waterfish species, but also attack the freshwater fish species like an ornamental fish, guppy, Poicelia reticulata[20], Acipenser sp [21], fish medaka (Oryzias latipes) [19], largemouth black bass Micropterus salmoides [22], and tilapia, Oreochromis niloticus (L.)[23][24].The genetic characterization confirmed that VNN infecting freshwater fish species was belong to the RGNNV genotype [19][25][24] and the SJNNV genotype [19].

Related to the possibility of genetic variation onVNN infected tilapia, it is important to know the virus variants by performing DNA sequencing VNN, followed by phylogenetic analysis, so as to know the kinship between VNN variants found intilapia. In the present research, a natural outbreak of VNN in tilapia (Oreochromis sp.) farmed in mid-Java in Indonesia was investigated using molecular genetic characterization.

\section{METHODS}

\section{Fish Sampling}

The samples used are a tilapia juvenile size $5-7 \mathrm{~cm}$, with orno clinical symptoms, and taken at random in the cultivation of tilapiain Central Java in mid-December 2014.The number of samples was105pieces. All sampling is conducted anobservationof clinicalsymptoms, thena sample of the brain and the eyes were collected for analysis of virus (PCR). Tilapia juvenile of the same size were used as the control fish

\section{Reverse transcriptase PCR (RT-PCR)}

The process of reverse-transcriptase PCR was performed using the Quick Access - AMV® RT-PCR (Promega) followed by nested PCR using Taq ${ }^{\circledR}$ Go Green Master Mix (Promega) with 
the same primer and marker from Kapa Universal Ladder. The reaction process conducted by the protocol of each kit, to a final concentration of each primer $2.5 \mu \mathrm{M}$. RT-PCR reactions Nested PCR was performed using a thermal cycler (GeneAmp® PCR System 9700, Applied Biosystems). Specific F2 primer (5'- GTC AGT CGT GTG TCG CAT CT-3 '), R3 (5'- CGA GTC ACG AAC GGT GAA GA-3'), NF2 (5 '-GTT CCC TGT ACA ACG ATT CC-3 '), and NR3 (5'-GGA GAC TTT GGG GCT GCT CA -3') [26] were used to amplify regions of the coat protein varies Betanodavirus. RT-PCR cycle conditions are: first incubation at $45{ }^{\circ} \mathrm{C}$ for $30 \mathrm{~min}$ followed by reverse transcriptase inactivation at $94{ }^{\circ} \mathrm{C}$ for $2 \mathrm{~min}$; then 40 cycles consisting of $94{ }^{\circ} \mathrm{C}$ for $30 \mathrm{~s}$, $60{ }^{\circ} \mathrm{C}$ for $30 \mathrm{~s}$, and $72{ }^{\circ} \mathrm{C}$ for $45 \mathrm{~s}$; and 1 cycle of $72{ }^{\circ} \mathrm{C}$ for $10 \mathrm{~min}$. Nested PCR cycle conditions was the same as RT-PCR cycle conditions without reverse-transcriptase process. Products have been amplified and then analyzed for using an electrophoresis in 1.6\% agarose gel stained with SYBR after save (Invitrogen).

\section{Sequencing Analysis}

Amplicons on agel purified was conducted using the QIAQuick®PurificationKit,according to the manufacturer's instructions. Results of purification were sequenced using BigDye ${ }^{\circledR T e r m i n a t o r ~ C y c l e ~ S e q u e n c i n g ~(A p p l i e d ~ B i o s y s t e m s), ~ a c c o r d i n g ~ t o ~ t h e ~ m a n u f a c t u r e r ' s ~}$ instructions. Sequencing cycle conditions were as follows $96^{\circ} \mathrm{C}, 0^{\circ} \mathrm{C}$ and $60^{\circ} \mathrm{Cfor} 10 \mathrm{~s}, 5 \mathrm{~s}$ and for $4 \mathrm{~min}$, respectively for 25 cycles. Purification of the product cycle sequencing was conducted using ethanol precipitation/EDTA. Denaturation carried out at a temperature of $95^{\circ} \mathrm{C}$ for 5 min by adding Hi-Di formamide1:1 into the product purification. Capillary electrophoresis is conducted by a sequencer Applied Biosystem3130 DNA Analyzer.

\section{Phylogenetic Analysis}

Results sequences in the sample was aligned by the contained data base in Gene Bank (NCBI) using the ClustalW software [27]. Phylogenetic tree constructed by ClustalW and then displayed with Tree View [28]. Phylogenetic tree describing the relationships among species was determined using a method of Neighbour-Joining (NJ tree) [29]. Reliability NJ tree using the boot strap method Felsenstein was concluded by 1000 replication.

\section{RESULT AND DISCUSSION}

\section{RT-PCR and sequencing}

RT-PCR amplification with specific primers shows the specific band at $294 \mathrm{bp}$ on agarose gel (Fig. 1a). The PCR products were then sequenced at 275-280 nucleotide bases as shown in Figure $1 b$.

Sequences results were compared to genotype VNN based on data from GeneBank that show that VNN from tilapia juvenile has a little difference with the nucleotide base pairs isolates for comparison, which isolates AY690596.1 (RGNNV) with values aligned score of 97. For isolate of EU236149.1(TPNNV), EU236147.1(BFNNV), and AB056572.1(SJNNV), each having a value of aligned score 69, 78, and 68, respectively. It can be state that the VNN isolates from tilapi ajuvenile has a high homologous with VNN of genotype RGNNV.Similar research regarding mass mortality in tilapia larvae infected VNN in Thailand als oshowed the high homologous and closely related to genotype RGNNV [24], from a reading o three base pairs (triplet) which is the genetic code (codon).

Phylogenetic tree reconstruction is conducted by matching the entire sequence of nucleotides, so it can display the form branching of isolates and species (genotypes) for comparison. Branch on the phylogenetic tree representing the relationships among the units, describe the relationship ancestral descent while the branch length represents the amount of evolutionary change that occurs between two nodes (branching point). In the construction of phylogenetic trees were performed in this study is based on the neighbor-joining method using software MEGA6 [30] that compares the sample isolates (tilapia 2015VNN) with 4 genotype VNN, 
namely barfin Flounder Nervous Necrosis Virus (BFNNV), Striped Jack Nervous Necrosis Virus (SJNNV), Tiger Puffer Nervous Necrosis Virus (TPNNV) and Red-spotted Grouper Nervous Necrosis Virus (RGNNV). Isolates tilapia 2015VNN has the closest kinship with Red spotted isolates grouper nervous necrosis virus (RGNNV), which is about $99 \%$. So to say that the VNN infected tilapia juvenile derived from genotyping RGNNV, as shown in Fig. 2.

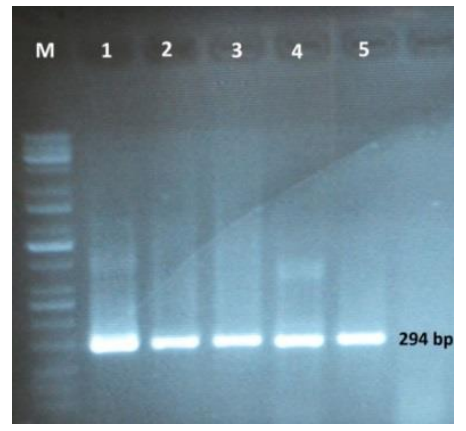

(a)

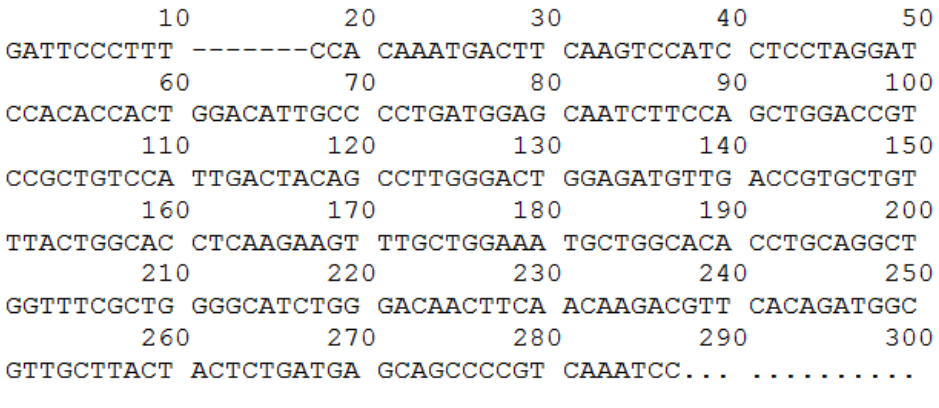

(b)

Figure1. (a) Detection of VNN gene from tilapiaby RT-PCR amplification.

Lanes M. DNA ladder, $1 \&$ 3: amplified product from total nucleic acids extracted from brain of tilapia; 2 \& 4: eye; amplified product from total nucleic acids extracted from brain; 5: Positive Control; (b) Sequence result

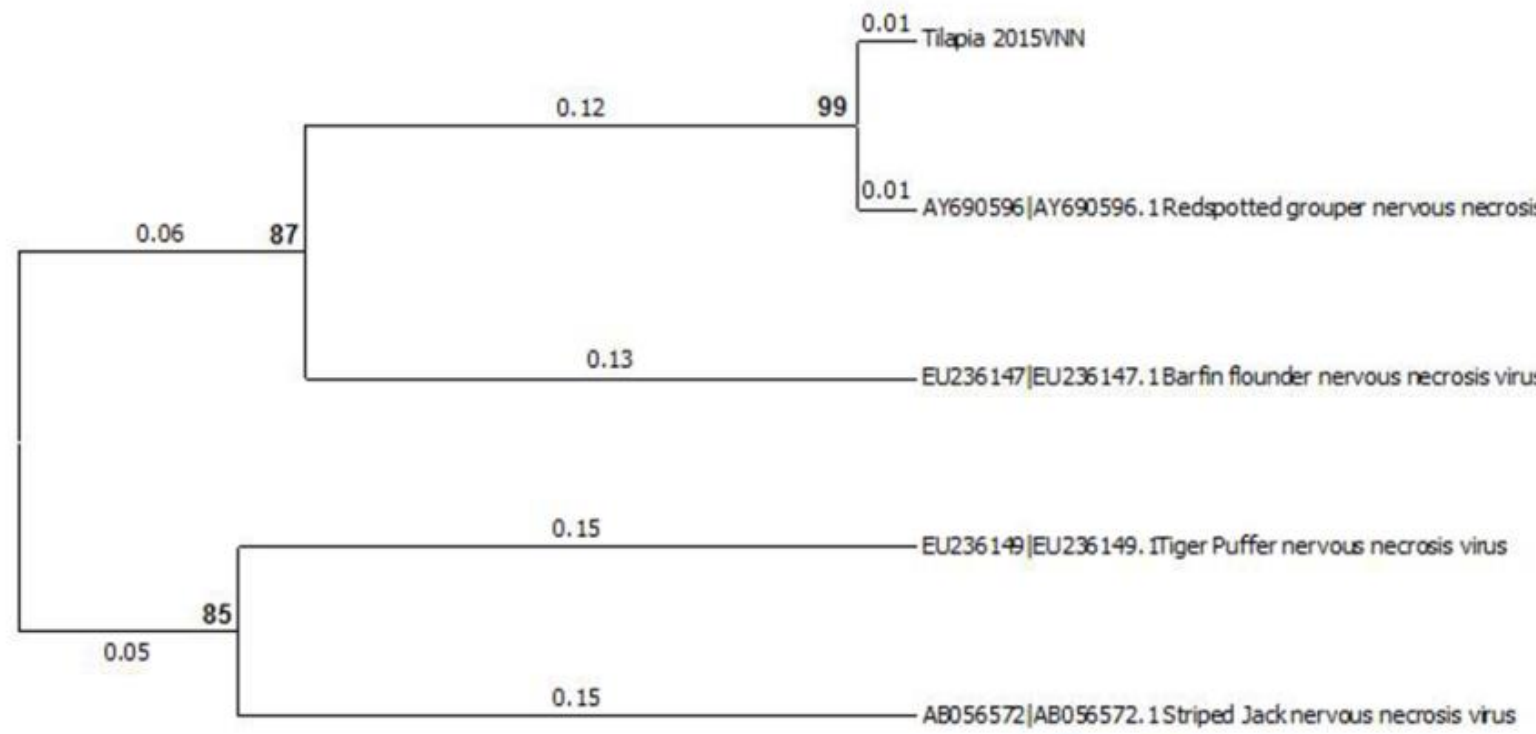

Figure 2. Phylogenetic tree constructed by protein gene sequences base of Tilapia-2015-VNN and other published isolates of betanodavirus. The tree was designed using Neighbor-Joining methods

Tilapia used in this study came from fresh water while the VNN is a disease that infects many species of saltwater fish. It showed that VNN has the ability to infect across species and adapt to a new host species [19]. A specific host on the most viral infections are usually controlled by the interaction with a viral surface protein receptors on the surface of target cells precisely [31], so long as the tilapia have receptors that can bind to the attachment site (s) virus particles, then certainly virus will entry into host cells (tilapia), because it does not directly host cell have facilitated the virus to enter the cell [32]. The tilapia have such receptors HSC70, as well as groupers [33], which specifically alleged that the virus can perform attachment and involved in an interaction that could cause the virus to enter the body tilapia. Interactions between viruses and cellular receptors is a dynamic process chain that allows the entry of the virus into the cell [34][35]. 
Based on sequencing probes followed by BLAST, it shows that the VNN that infect tilapia is similar VNN infecting both snapper and grouper. After matching to theGeneBank data,isolates of tilapia 2015VNN (VNN fromtilapia) has a nucleotide sequence that is similar to T156700 isolates of identity snapper with a max value of $100 \%$ (data not shown), whereas fo rEA-150102-IL isolates from grouper with max identity value of $99 \%$ (data not shown). It indicate that tilapia isolates of $2015 \mathrm{VNN}$ has a nucleotide sequence that is almost same and there is a little difference of base pairs of nucleotides. Phylogenetic tree is reconstructed by matching the entire sequence of nucleotides so that it can display the form branching of isolates and species comparison. The results of the phylogenetic analysis showed that the VNN infected tilapia derived from genotype RGNNV. RGNNV is one of genotypes VNN, who lived in the temperature range of $25-30^{\circ} \mathrm{C}$, where the condition of Indonesia is at that temperature range.

There are the homologous in both VNN infecting fresh water fish and VNN infecting sea water fish. Betanodavirus isolated from Epinephelus taurine (taurine Epinephelus Nervous Necrosis Virus=ETNNV) has high homolouges with virus isolated from freshwater fish Poecili areticula (Guppy Nervous Necrosisvirus=GNNV) [20]. Virus isolated fromMicropterus salmoides has high homologous with RGNNV [22]. In this study, VNN infected tilapia has homologous with RGNNV. It can be stated that Betanodavirus in freshwater fish potential is derived from Betanodavirus in sea water fish.

\section{CONCLUSION}

The existence of VNN in tilapia is one of the problems that must be handled. This study results show that VNN infected tilapia has homologous with RGNNV. This research finding has enlarged the recognized susceptible hosts of the VNN with freshwater fish. Further studies, it is needed to investigate the epidemiology and the mode of transmission to know why VNN are found in both freshwater and marine fishes in Indonesia.

\section{ACKNOWLEDGMENTS}

This work was supported by the Ministry of Research, Technology and Higher Education, Republic of Indonesia; through the of LeadingResearch of University (PUPT) with contract no: 033/SP2H/LT/DRPM/II/2016.

\section{REFERENCES}

[1] M. T. Ridha, Aquac. Res., 37 ( 2), 172-179 (2006).

[2] L. Bigarré, J. Cabon, M. Baud, M. Heimann, A. Body, F. Lieffrig, and J. Castric, J. Fish Dis. 32, 667-673 (2009).

[3] G. G. Tsadik and A. N. Bart, Aquaculture, 272 (1-4),380-388 (2007).

[4] FAO, "FAO Fisheries \& Aquaculture - Cultured Aquatic Species Information Programme Oreochromis niloticus (Linnaeus, 1758 ), Available:

http://www.fao.org/fishery/culturedspecies/Oreochromis_niloticus/en\#tcNA008C. [Accessed: 04-Jun-2015].

[5] A. Widiarti, "Indonesia tilapia production and trade," in International Conference on Tilapia, 2015.

[6] K. Mori, T. Nakai, K. Muroga, M. Aarimoto, K. Mushiake, and I. Furusawa, Virology 187, 368-371 (1992).

[7] B. L. Munday, J. Kwang, and N. Moody, J. Fish Dis. 25 (3), 127-142 (2002).

[8] T. Nishizawa, M. Furuhashi, T. Nagai, T. Nakai, and K. Muroga, Appl. Envir. Microbiol. 63 (4), 1633-1636, (1997). 
[9] I. S. Azad, K. P. Jithendran, M. S. Shekhar, A. R. Thirunavukkarasu, and L. D. de la Pena, Aquaculture 255, 39-47 (2006).

[10] K. Yoshikoshi and K. Inoue, J. Fish Dis. 13 (1), 69-77 (1990).

[11] J. S. Glazebrook, M. P. Heasman, and S. W. Beer, J. Fish Dis. 13 (3), 245-249 (1990).

[12] B. Bloch, K. Gravningen, and J. Larsen, “Dis. Aquat. Organ. 10 (1984), 65-70 (1991).

[13] Zafran, I. Koesharyani, F. Johnny, K. Yuasa, T. Harada, and K. Hatai, Fish Pathol. 32 (2), 95-96 (2000).

[14] U. Yanuhar, E. Gusman, and D. Arfiati, Adv. Environ. Biol. 6 (1), 388-396 (2012).

[15] R. Yuwanita, U. Yanuhar, and Hardoko, Adv. Environ. Biol.7 (6), 1074-1081 (2013).

[16] J. Ransangan and B. O. Manin, Veterinary Microbiology. Elsevier, 2010.

[17] P. Hick, G. Schipp, J. Bosmans, J. Humphrey, and R. Whittington, Aquaculture 319 (1-2), 41-52 (2011).

[18] D. K. Gomez, K. Mori, Y. Okinaka, T. Nakai, and S. C. Park, Aquaculture 302 (3-4), 58163 (2010).

[19] R. Furusawa, Y. Okinaka, and T. Nakai, J. Gen. Virol.87 (Pt 8), 2333-9 (2006).

[20] A. Hegde, H. C. Teh, T. J. Lam, and Y. M. Sin, Arch. Virol. 148 (3), 575-86, (2003).

[21] F. Athanassopoulou, C. Billinis, and T. Prapas, Dis. Aquat. Organ. 60 (3), 247-52 (2004).

[22] G. Bovo, a. Gustinelli, F. Quaglio, F. Gobbo, V. Panzarin, a. Fusaro, F. Mutinelli, M. Caffara, and M. L. Fioravanti, Dis. Aquat. Organ. 96, 45-54 (2011).

[23] L. Bigarré, J. Cabon, M. Baud, M. Heimann, A. Body, F. Lieffrig, and J. Castric, J. Fish Dis. 32 (8), 667-73 (2009).

[24] J. Keawcharoen, S. Techangamsuwan, A. Ponpornpisit, E. D. Lombardini, T. Patchimasiri, and N. Pirarat, J. Fish Dis. 38 (1), 49-54 (2015).

[25] C. Maltese and G. Bovo, Ittiopatologia4, 93-146 (2007).

[26] OIE, "Access online: OIE - World Organisation for Animal Health," Manual of Diagnostic Tests for Aquatic Animals, 2013. Available: http://www.oie.int/international-standardsetting/aquatic-manual/access-online/. [Accessed: 01-Jul-2015].

[27] J. D. Thompson, D. G. Higgins, and T. J. Gibson, Nucleic Acids Res. 22 (22) 4673-80 (1994).

[28] R. D. Page, Comput. Appl. Biosci. 12 (4), 357-8 (1996).

[29] N. Saitou and M. Nei, Mol. Biol. Evol. 4 (4), 406-425 (1987).

[30] K. Tamura, G. Stecher, D. Peterson, A. Filipski, and S. Kumar, Mol. Biol. Evol. 30(12), 2725-9 (2013).

[31] E. Baranowski, Science 292 (5519), 1102-1105 (2001).

[32] Y. Ito, Y. Okinaka, K. Mori, T. Sugaya, T. Nishioka, M. Oka, and T. Nakai, Dis. Aquat. Organ. 79(3), 199-205 (2008).

[33] J. S. Chang and S. C. Chi, J. Virol. 89 (1), 61-70 (2015).

[34] A. M. Haywood, J. Virol. 68(1), 1-5, (1994).

[35] S. J. Schaulies, J. Gen. Virol. 81 (6), 1413-29 (2000). 